toissa usein esiintyvä Gorbatšovin ensimmäinen matkapuhelu, jonka monet sijoittavat Ouluun ja Teknologiakylään, vaikka puhelu soitettiin Helsingistä. Näyttelyssä matkapuhelin on sijoitettu Mihail Gorbatšovia ja Raisa Gorbatšovaa sekä heidän kansainvälistä mainettaan esittelevään vitriiniin ja Oulun-vierailuun keskittyvässä vitriinissä vielä palataan muistitiedossa toistuvaan puhelun sijoittamiseen Ouluun. Muistitietoon liittyy myös näyttelykäynnillä kuulemani keskustelu, jossa museovieraat pohtivat, oliko erään vierailua muistelleen mainitsema kevyen liikenteen silta tosiaan paikallaan jo vuonna 1989. Vaikka siltaa ei olisi ollutkaan ja vaikka Gorba ei soittanut kuuluisaa puhelua juuri Oulusta, molemmat näistä ovat esimerkkejä siitä, miten muisti tuottaa yhteyksiä ajallisesti yhteensopimattomien tapahtumien välille. Oulun ja nykyaikaisen teknologian kytkös kannustaa sijoittamaan myös matkapuhelun juuri vierailusta hullaantuneeseen kaupunkiin.

Näyttelystä jää vierailijalle päällimmäiseksi tunnelmaksi Gorbatšovin hahmoon tiivistyvä 1980-luvun lopun optimismi. Lisäksi hämmästyttävältä tuntuu, miten monella vaikuttaa olevan muistoja vierailusta ja Gorbatšovista, kun niitä vain ymmärretään kysyä. Omiin 1980-luvulle sijoittuviin lapsuusmuistoihini valtiovierailu ei kiinnity, varmaankin juuri siksi, kuten Leninmuseon eläkkeellä oleva johtaja Aimo Minkkinen näyttelyssä kuullussa haastattelussa totesi, että Tampere jäi yllättäen paitsi Gorbatšovin vierailusta. Valtiovierailun sijaan muistankin Tampereen keskustasta sabluunalla tehdyn seinäkirjoituksen, jossa luki "Gorba on kova jätkä". Tämän muistikuvan materiaalisia jälkiä ei taida enää löytyä mistään.

Näyttelyyn voi tutustua myös nettisivulla https://www.ouka.fi/oulu/luuppi/gorba-tulee. Gorbatšovin vierailun muistoja kertään sähköpostitse: gorbaoulussa@gmail.com sekä Facebook-ryhmässä: https://www.facebook. com/groups/413370846137683/.

Riikka Taavetti

\title{
Toveri lapsi odottaa äitiä
}

Toveri lapsi (Seltsimees laps, Viro 2018). Käsikirjoitus ja ohjaus Moonika Siimets. Pääosissa Helena Maria Reisner, Tambet Tuisk, Eva Koldits, Liina Vahtrik, Juhan Ulfsak, Julia Aug, Lembit Peterson, Maria Klenskaja.

Moonika Siimetsin (s. 1980) käsikirjoittama ja ohjaama elokuva Toveri lapsi perustuu lastenkirjailija Leelo Tungalin (s. 1947) omiin lapsuusmuistoihin, jotka ovat ilmestyneet kolmena kirjana ja elokuvan myötä myös yhteispainoksena. Ensimmäinen osa on julkaistu suomeksi tänä vuonna Anja Salokanteleen ja Heli Laaksosen käännöksenä nimellä Toveri lapsi: vielä yksi kertomus onnellisesta lapsuudesta (Arktinen Banaani). Viron itsenäisyyspäiväksi 2018 valmistunut elokuva keräsi kotimaassa täysiä saleja ja on ollut teatterilevityksessä myös Suomessa. Elokuvassa eletään Neuvosto-Virossa, aivan 1950-luvun alussa. Asiat näytetään, paljoakaan ei selitetä, mihin lapsen näkökulma on omiaan. On kuitenkin hyvä tietää, että kirjailijan äiti oli Tallinnan eteläpuolella sijaitsevan Ruilan moisiossa toimineen koulun rehtori, joka joutui Siperiaan opetettuaan lapsille vääränlaista historiaa. Toisin kuin elokuvassa, Tungal oli vasta 3-vuotias, kun äiti vietiin pois, ja hän eli sen jälkeen opettajaisänsä kanssa odottaen äidin paluuta.

Elokuvan alussa äiti Helmes (Eva Koldits) kertoo kuusivuotiaalle Leelolle (Helena Maria Reisner), että joskus, kun on oikein paha olla, voi auttaa, että puhuu puille. Leelo haluaa tietää, kuuntelevatko puut. Samana päivänä perhe muuttaa pois isosta talosta. Nalle jää ikkunalaudalle nököttämään. Uusi koti on vaatimaton mökki kävelymatkan päässä. Isä Feliks (Tambet Tuisk) nakuttelee rikkinäisten ikkunalasien paikalle vanerilevyjä. Leelo livahtaa ulos ja kävelee sateessa takaisin kartanoon. Nyt siellä on vieras täti (Julia Aug). Leelo nappaa nallensa ja piiloutuu, mutta täti löytää hänet. Äiti juoksee tiellä vastaan, ja täti nuhtelee äidin venäjäksi: Leelo on huonosti kasvatettu lapsi. Pian sotilaat tulevat tutkimaan perheen asunnon, ja äiti viedään kuorma-autolla pois. Leelo uskoo, että se on hänen syytään. Koska äiti on sanonut jäähyväisiksi, että nyt Leelon pitää olla kiltti tyttö, hän yrittää parhaansa mukaan; sittenhän äiti voi tulla takaisin. Välillä kun tuntuu oikein vaikealta, Leelo puhuu puille ja toivoo, että ne kuulevat. Ja ehkä auttavat.

Siimets kertoo tarinan Leelon näkökulmasta, 
mutta kaksoisvalottaa kohtauksiin lisäksi päähenkilön tajunnan ylittävän ja häntä ympäröivän aikuisten maailman. Ylivoimaiset solmut, joiden kanssa pieni tyttö käy jatkuvaa kamppailua, avautuvat aikuiselle katsojalle. Kilttinä oleminen ei aina ole helppoa, ja Leelo epäonnistuu monta kertaa. On vaikea tietää, mikä on kilttiä ja mikä ei ole. Jos käsketään olemaan hiljaa, tarkoittaako se oikeasti sitä? Olisihan melkein valehtelua, jos Leelo ei kertoisi kampaamossa venäläiselle naiselle, että täti on kyllä paikalla, mutta meni takahuoneeseen. Venäläiset on esitetty elokuvassa ylipäätään yksiselitteisesti vihollisina ja miehittäjinä.

Leelo yrittää parhaansa mukaansa sopeutua Viron uuteen neuvostotodellisuuteen. Hän pitää pioneereista ja haluaisi itsekin olla sellainen, pioneerithan ovat kilttejä ja kunnollisia. Leelosta on hienoa, kun bussin rahastajatäti kutsuu häntä toveriksi. Kun Leelo laulaa mielestään hienon pioneerilaulun, isää nolostuttaa ja tämän kavereita hymyilyttää. Leelolle asioita ei selitetä, mutta annetaan ymmärtää. Kun hän esimerkiksi haluaa kuunnella Stalinin puhetta, isä sulkee radion ja nostaa sen tytön ulottumattomiin.

Juhan Ulfsak on saanut periaatteessa saman inhan NKVD-miehen roolin kuin Hannu-Pekka Björkman 1930-luvulle sijoittuvassa Ikitieelokuvassa (Suomi 2017, ohj. Antti-Jussi Annila). Varik on virolainen, isän ja äidin entinen koulukaveri, mutta työskentelee nyt neuvostomiehittäjille. Ulfsak tekee Varikista susimaisen hyytävän hahmon, kömpelön epäihmisen, joka onnistuu vain irvistämään, vaikka yrittää asetella hymyä naamalleen. Varik yrittää saada käsiinsä isän Viron itsenäisyyden aikaiset urheilumitalit ja väittää, että mitalit auttaisivat isää saamaan paremman työn. Leelo kuitenkin tietää jo, että mitalit pitäisi heittää jokeen, niin kuin isoäiti teki.

Tarina on yksinkertainen ja etenee tunnelmasta toiseen rauhallisesti soljuvin kuvin, joiden yksityiskohtiin on todella panostettu. Näyttelijät asettuvat pakottomasti ja hienoja vivahteita löytäen rooleihinsa - osaksi aikaa ja maailmaa, jossa Leelo yrittää ratkoa kiltteyden salaisuutta. Jo lähes kadonneita neuvostoajan jäänteitä löydettiin eri paikoista, ja ehyt 1950-luvun epookki luotiin yhdistelemällä paloja toisiinsa. Esimerkiksi elokuvan loppukohtaus on kuvattu kahdella vanhalla rautatieasemalla. Apuna käytettiin myös erikoistehosteita ajanmukaisten katunäkymien luomiseksi. Elokuvan hienoin hetki on ehdottomasti sen loppu, josta Leelo Tungal on itse sanonut olevansa nuorelle ohjaajalle kiitollinen. Elokuvassa korostuu virolaisten kansallistunne, suhde lauluun ja luontoon sekä viha miehittäjiä kohtaan. Toisaalta lähikuvassa on eräs lapsuus, joka on kaikesta huolimatta myös onnellinen.

Mia Öhman 